\title{
PENGARUH KETRAMPILAN BAHASA ASING TERHADAP KELANCARAN OPERASIONAL DI FOOD AND BEVERAGE PRODUCT HYATT REGENCY YOGYAKARTA
}

\author{
Nuharani Erningdyah Kurniyati ${ }^{1}$, Emanuel Adit ${ }^{2}$ \\ ${ }^{1,2}$ Sekolah Tinggi Pariwisata AMPTA, Yogyakarta, Indonesia, email: nuh4r4n1@ yahoo.co.id
}

\begin{abstract}
ABSTRAK
Artikel ini bertujuan untuk mengetahui pengaruh kecakapan berbahasa Inggris karyawanfood and beverage product kitchen Hyatt Regency Yogyakarta ketika melaksanakan pekerjaannya. Jenis penelitian yang digunakan adalah penelitian deskriptif dengan kuisioner sebagai instrumen pengumpulan datanya. Metode penelitian yang digunakan kuantitatif asosiatif yaitu penelitian yang bertujuan untuk mengetahui pengaruh ataupun hubungan antara dua variabel atau lebih. Teknik pengambilan sampel dengan teknik sensus atau sampling jenuh yaitu semua populasi,seluruh staff Food and Beverage Product Department Kemangi Bistro Hotel Hyatt Regency Yogyakartayang berjumlah 10 orang menjadi sample. Hasil penelitian menunjukkan bahwa kecakapan berbahasa Inggris (kemampuan menulis, kemampuan berbicara, kemampuan membaca, kemampuan mendengarkan) berpengaruh terhadap kelancaran operasional Food And Beverage Product Kitchen Hyatt Regency Yogyakarta. Diketahui Hasil koefisiensi determinasi atau R Square sebesar 0,965 atau 96,5\%. Hal ini berarti variabel yang diteliti secara simultan berpengaruh terhadap variabel Kelancaran Operasional sebesar 96,5\%. Sedangkan sisanya 3,5\% dipengaruhi oleh variabel lain di luar persamaan regresi ini atau variabel yang tidak diteliti.
\end{abstract}

Kata kunci: Keterampilan Bahasa Inggris, kelancaran operasional

\section{THE INFLUENCE OF FOREIGN LANGUAGE S}

\section{KILLS ON OPERATIONAL FLUENCY IN THE FOOD AND BEVERAGE PRODUCT AT THE HYATT REGENCY YOGYAKARTA.}

The purpose of this study was to determine the effect of the employees' English proficiency at the food and beverage product kitchen of the Hyatt Regency Yogyakarta when carrying out their work. The type of research used is descriptive research with a questionnaire as a data collection instrument. The research method used is associative quantitative research, which aims to determine the effect or relationship between two or more variables. The sampling technique is using census or saturated sampling, using all the population of all 10 staff members of the Food and Beverage Product Department of the Kemangi Bistro Hotel Hyatt Regency Yogyakarta. The results showed that English proficiency (writing skills, speaking skills, reading skills, listening skills) affects the smooth operation of Food and Beverage Product Kitchen Hyatt Regency Yogyakarta. It is known that the coefficient of determination or $R$ Square is 0.965 or $96.5 \%$. This means that the variables studied simultaneously affect the Operational Smoothness variable by $96.5 \%$. While the remaining $3.5 \%$ is influenced by other variables outside this regression equation or variables that are not studied.

Keywords: English language skills, operational fluency 


\section{PENDAHULUAN}

Hyatt Regency Yogyakarta merupakan salah satu hotel berstandar internasional di Yogyakarta. Sebagai hotel yang bertaraf internasional, Hyatt Regency Yogyakarta diminati tamu mancanegara. Dengan demikian karyawan di Hotel Hyatt Regency dituntut untuk dapat berbahasa asing, paling tidak bahasa Inggris dengan baik, karenastandar Internasional yang disandangnya. Kemampuan bahasa asing memudahkan para karyawan dalam berkomunikasi dengan tamu dari mancanegara khususnya. Komunikasi dalam bahasa Inggris juga digunakan dalam kegiatan operasional di hotel sehari-hari akibat dari konsekwensi hotel berstandar Internasional.

Bisa berbahasa Inggris bagi karyawan atau staf hotel internasional merupakan suatu keharusan untuk dapat bekerja di departemen apapun mereka ditempatkan. Memiliki staf restoran yang mempunyai kemampuan berbahasa Inggris sangat penting apabila hotelnya memiliki standar internasional, karena hampir dapatdipastikan segala macam menu berbahasa asing. Terlebih lagi bila manager atau chef nya orang asing, maka tidak bisa dihindari bahasa Inggris juga digunakan dalam instruksi memasak, nama peralatan, dan bahan baku. Kemampuan berbahasa Inggris yang memenuhi standar penggunaan di lingkungannya juga dinilai sangatlah penting agar tidak terjadi kesalahan dalam berkomunikasi atau miss communication yang bermuara pada miss understanding.

Hasil penelitian terdahulu menyatakan bahwa pengaruh kemampuan pemahaman istilah Bahasa Inggris lebih besar dibandingkan dengan kemampuan pemahaman operasi dasar matematika terhadap kemampuan belajar teknlogi informasi dan komunikasi. Bahasa merupakan alat utama manusia dalam berkomunikasi antara pengirim pesan (sender) dengan penerima pesan (receiver) baik secara individu, maupun kelompok dalam kehidupan sehari-hari. Berkomunikasi dapat dilakukan dalam berbagai bahasa baik itu menggunakan bahasa daerah, bahasa nasional, maupun bahasa asing, bahkan bahasa non verbal.

Era tanpa batas sekarang ini, memiliki kemampuan berbahasa asing merupakan suatu keharusan yang "memaksa" setiap orang-agar bisa mengikuti trend dan perkembangan di belahan dunia lain. Oleh sebab itu, bahasa asingsangat dibutuhkan bagi staf hotel terutama yang bertaraf internasional sebagai sarana untuk berkomunikasi dengan tamu dari negara yang berbeda bahasanya.

Keterampilan dalam berbahasa asing merupakan salah satu syarat yang dibutuhkan, jika ingin bekerja di suatu perusahaan Internasional apalagi bekerja di bidang pariwisata, termasuk hotel. Bahasa asing, khususnya bahasa Inggris digunakan sebagai standar kemampuan berbahasa asing, dengan tujuan untuk memudahkan dalam berkomunikasi dengan pihak luar, seperti dalam melayani tamu, atasan atau sejawat yang kemungkinan berasal dari luar negeri.

Bahasa adalah salah satu warisan manusia yang memainkan peranan penting dalam kehidupan manusia itu sendiri, seperti dalam berpikir, menyampaikan gagasan, dan berkomunikasi dengan yang lainnya. "Language is a unique human inheritance that plays the very important role in human's life, such as in thinking, communicating ideas, and negotiating with the others".

Secara umum bahasa digunakan sebagai alat untuk berkomunikasi (Siahaan, 2008). Rachman (2010) menyebutkan bahwa food and beverage department yaitu bagian yang bertugas mengolah, memproduksi dan menyajikan makanan dan minuman untuk keperluan tamu hotel, baik dalam kamar, restoran/coffee-shop, banquet (resepsi, pertemuan), makanan karyawan, dan sebagainya.Dengan tugas mengolah, memproduksi makanan dan minuman bukan berarti staf food and beverage tidak perlu berkomunikasi saat melaksanakan tugas, bahkan komunikasi sangat diperlukan karena merupakan kerja team, bukan individu. 
Bahasa Inggris menjadi salah satu bahasa utama yang digunakan di hotel Hyatt Regency Yogyakarta baik itu dalam pelayanan maupun operasional di dalam departemen, termasuk juga di Food and Beverage Department. Akan tetapi, dalam observasi di Food and Beverage Product peneliti masih menemukan beberapa sumber daya manusia yang masih kurang lancar berbahasa Inggris. Oleh sebab itu, sangat menarik untuk melakukan penelitian apakah ada pengaruh ketrampilan bahasa asing terhadap kelancaran operasional di food and beverage product di Hyatt Regency Yogyakarta.

\section{LITERATUR REVIEW}

\section{Food and Beverage Department}

(Sulastiyono, 2011) mengatakan bahwa Food and Beverage Product adalah"bagian yang bertugas mengolah, memproduksi dan menyajikan makanandan minuman untuk keperluan tamu hotel, baik dalam kamar, restoran atau Coffe Shop, Banquet (resepsi, pertemuan), makanan karyawan, dan sebagainya. Secara umum tugas bagian Food and Beverage adalah:

\section{Persiapan}

Penampilan harus mencerminkan kepribadian yang bersih, sehat, rapi, dan cekatan karena tamu langsung melihat bagaimana staf itu bekerja. Hal ini bertambah penting lagi jika bekerja di dapur yang terbuka dan langsung dapat dilihat oleh tamu (open kitchen) seperti salah satu restoran yang dimiliki oleh Hyatt Regency Yogyakarta yaitu Kemangi Bistro. Mise En Place atau preparation untuk semua peralatan dan segala bahan dipersiapkan agar kegiatan masak lebih lancar dan efisien.

\section{Memproduksi dan Penyajian}

Food and Beverage Product di Hotel Hyatt Regency Yogyakarta termasuk dalam kategori dapur besar atau large brigade, maka setiap seksi: local section, western section, cold kitchen section melakukan operasionalnya masing-masing dari persiapan, memproduksi sampai penyajian sesuai dengan spesifikasinya.

\section{Bahasa}

Bahasaadalah salah satu warisan manusia yang memainkan peranan penting dalam kehidupan manusia itu sendiri, seperti dalam berpikir, menyampaikan gagasan, dan berkomunikasi dengan yang lainnya. (Siahaan, 2008). Seperti yang terjadi di Food and Beverage bahasa memiliki fungsi interaksional yang dapat dimaknai bahwa bahasa itu dapat digunakan untuk menjamin terjadinya interaksi, memantapkan komunikasi, dan mengukuhkan komunikasi dan interaksi antar pegawai/staf yang ada di departemen tersebut.Asesmen dilakukan untuk mengetahui kompetensinya dalam keterampilan berbahasa Inggris bagi stafyang menurut(Wahyuni \& Ibrahim, 2012) dibagi dalam empat kategori yaitu: (1) Asesmen keterampilan mendengarkan. Mendengarkan merupakan proses kegiatan mendengarkan untuk memperoleh informasi, menangkap isi, atau pesan serta memahami makna komunikasi yang telah disampaikan oleh si pembicara melalui ujaran atau bahasa lisan; (2) Asesmen keterampilan berbicara. Berbicara adalah kemampuan untuk berkomunikasi, agar dapat menyampaikan pikiran secara efektif; (3) Asesmen keterampilan membaca; (4) Asesmen keterampilan menulis. Menulis merupakan pengekspresian ide, gagasan, pikiran, atau perasaan ke dalam lambng-lambang kebahasaan.

\section{Tinjauan Mengenai Bahasa Inggris}

Melalui website https://krishnalearningcenter.com, diakses pada tanggal 19 Maret 2019 terdapat pendapat mengenai fungsi bahasa asing terutama bahasa Inggris

Semakin banyak perusahaan lokal Indonesia yang masuk ke pasar dunia, semakin banyak juga perusahaan internasional yang masuk ke pasar lokal. Maka penggunaan bahasa Inggris yang menjadi bahasa "bisnis" makin dirasakan sebagai suatu keharusan. Bahasa Inggris telah menjadi bahasa wajib setelah bahasa ibu. Oleh sebab itu, kemampuan bahasa Inggris menjadi sesuatu yang urgen 
dan mendesak, termasuk di dunia kerja dewasa ini.

\section{METODE}

Penelitian ini merupakan penelitian kuantitatif dengan pendekatan deskriptif. Penelitian ini mendeskripsikan peristiwa dan fakta yang ada di bagian food and beverage product kitchen, yang menunjukkan bahwa ada sumber daya manusia atau staff yang belum mampu berkomunikasi menggunakan bahasa asing (bahasa Inggris utamanya), sehingga memerlukan beberapa saat untuk merespon apa yang didengar atau disampaikan oleh atasannya. Keadaan seperti ini mungkin mengakibatkan operasional yang ada di dapur hotel terhambat atau tersendat, hingga berkurang kelancarannya dalam memberikan pelayanan kepada tamu.

Penelitian inidilakukan di Hotel Hyatt Regency Yogyakarta yang beralamat di Jl. Palagan Tentara Pelajar, Sariharjo, Ngaglik, Kabupaten Sleman, Yogyakarta. Pelaksanaan penelitian berlangsung selama kurang lebih 1 (satu) bulan.

Populasi dalam penelitian ini adalah seluruh staff di Food and Beverage Product Departement Kemangi Bistro Hyatt Regency Yogyakarta yang berjumlah 10 orang, karena jumlahnya sedikit, maka yang menjadi sampel adalah seluruh staff di Food and Beverage Product Kitchen Kemangi Bistro, Hotel Hyatt Regency Yogyakarta, sehingga penelitian ini dapat juga disebut sebagai penelitian populasi.

Adapun variabel dalam penelitian tentang pengaruh kemampuan berbahasa asing terhadap kelancaran operasional di Food \& Beverage Product adalah variabel kemampuan membaca, kemampuan berbicara, kemampuan mendengarkan, kemampuan menulis, dan kelancaran dalam operasional food \& beverage product.

Variabel kemampuan membaca dalam bahasa Inggris (X1) dengan indikator: (1) Mampu memahami tulisan dalam bahasa Inggris; (2) Mampu membaca dalam bahasa Inggris; (3) Dapat mengambil inti suatu tulisan dalam bahasa Inggris tanpa merubah arti dari tulisan tersebut.

Variabel kemampuan berbicara dalam bahasa Inggris (X2) dengan indikator: (1) Mampu berkomunukasi dalam bahasa Inggris; (2) Mampu merespon komunikasi dalam bahasa Inggris; (3) Mampu menyampaikan dan menceritakan pendapatnya menggunakan bahasa Inggris.

Variabel kemampuan mendengarkan dalam bahasa Inggris (X3) dengan indikator: (1) Mampu memahami percakapan dalam bahasa Inggris; (2) Mampu mengambil inti informasi yang diterima secara lisan dalam bahasa Inggris; (3) Mampu menceritakan kembali informasi dalam bahasa Inggris yang didengar tanpa merubah arti dari percakapan tersebut.

Variabel kemampuan menulis dalam bahasa Inggris (X4), dengan indikator: (1) Dapat menulis dalam bahasa Inggris; (2) Dapat menyampaikan informasi secara tertulis dalam bahasa Inggris; (3) Dapat menyampaikan informasi dalam bahasa Inggris tanpa merubah arti yang sesungguhnya.

Variabel Dependen (Y) yaitu kelancaran dalam operasional food \& beverage product dengan indikator: (1) Memperlancar penyampaian informasi di food and beverage product kitchen secara lisan; (2) Memperlancar penyampaian perintah di food and beverage product department secara lisan; (3) Memperlancar penyampaian perintah dan informasi di food and beverage product department secara tertulis.

\section{Metode Pengumpulan Data}

\section{Angket Kuesioner}

Parastaff yang ada di food and beverage productdiberi pertanyaan-pertanyaan tertutup yang berhubungan dengan operasional di food and beverage productdengan skorjawaban:

Skor 4 = Sangat Setuju (SS)

Skor $3=$ Setuju $(\mathrm{S})$

Skor 2 = Tidak Setuju (TS) 
Skor 1 = Sangat Tidak Setuju (STS)

Wawancara

Wawancara tidak terstruktur atau terbuka (tidak menggunakan pedoman wawancara), hanya berupa garis-garis besar permasalahan yang akan ditanyakanuntuk mendapatkan data yang mendalam dari responden.

\section{Observasi}

Peneliti melakukan pengamatan di lingkungan tempat kerja, melakukan komunikasi dengan staf Food and Beverage Product untuk mencaritahu tentang kelancaran komunikasi staff pada saat operasional di F\&B Product, pada saat proses kerja sedang berlangsung.

\section{HASIL DAN PEMBAHASAN}

\section{Deskripsi Hyatt Regency Yogyakarta}

Hyatt Regency Yogyakarta merupakan salah satu hotel bintang lima terbaik di Yogyakarta. Hotel Hyatt berpusat di Amerika dan mempunyai beberapa Hotel Hyatt yang tersebar ke seluruh dunia, dan salah satunya di Indonesia. Terdapat lima Hotel Hyatt yang tersebar di berbagai wilayah di Indonesia seperti Jakarta, Bandung, Surabaya, Bali dan Yogyakarta. Di Yogyakarta dikenal sebagai Hyatt Regency Yogyakarta.Hyatt Regency Yogyakarta terletak di Jalan Palagan Tentara Pelajar atau sebelah utara dari Kota Yogyakarta.Hotel ini mempunyai luas 24 hektar dan lanskap pemandangan yang indah. Hotel Hyatt mempunyai beberapa fasilitas yang disediakan untuk tamu seperti jumlah kamar 269 yang terdiri dari 209 Garden View Rooms, 51 Regency Club Rooms, 6 Junior suite, 2 Executive Suite, 1 Presiden Suite dan 3 ruang kamar untuk tamu yang berkebutuhan khusus.

Hotel Hyatt Regency Yogyakarta pernah menjadi hotel Hyatt terbaik kedua dari beberapa Hotel Hyatt di dunia. Hotel Hyatt Regency Yogyakarta mempunyai berbagai macam fasilitas hiburan dan olah raga seperti Gym, lapangan golf 9-hole, lapangan tenis, lapangan futsal, kolam renang yang dilengkapi dengan papan luncur air sepanjang 70 meter, Health Clubyang terdiri dari jacuzzi, sauna, spa \& salon serta jogging track sepanjang 2,5 km., dan tentunya restaurant yang mengurus kebutuhan makan dan minum.

Hyatt Regency Yogyakarta didirikan pada tahun 1970-an olehBapak Jan Darmadi yang bergerak dalam bidang property dan real estate.Dibangun dengan mereplikasi konsep Candi Borobudur. Hotel bintang lima ini menyediakan pemandangan spektakuler Gunung Merapi dan Merbabu. Tak ketinggalan dengan Candi Bentar dan reruntuhan batu candi yang ada di pelataran hotel, membawa pengunjung kedalam nuansa eksotika Jawa yang sesungguhnya.Hotel dengan tujuh lantai ini memiliki 269 kamar yang terdiri dari 9 kamar suite, 51 kamar Regency club dan 209 kamar garden view. Berdiri di lahan seluas 22 hektar, Hyatt Regency Yogyakarta menyediakan beragam fasilitas hiburan dan olah raga yang menarik, seperti lapangan golf 9-hole, lapangan tenis, lapangan futsal, kolam renang yang dilengkapi dengan papan luncur air sepanjang 70 meter, health club yang terdiri dari jacuzzi, sauna, spa \& salon serta jogging track sepanjang $2,5 \mathrm{~km}$. Selain itu, Hyatt Regency Yogyakarta juga menyediakan tur sepeda dan tur andong mengelilingi hotel untuk memberikan pengalaman yang berbeda ketika berlibur di Yogyakarta.

Hadir pula Kemangi Bistro yang mengusung konsep open-show kitchen dengan menyediakan berbagai paket menarik dan terjangkau seperti sunday brunch, romantic dinner di Candi Bentar dan Ramayana Night Market yang menghadirkan sendra tari Ramayana dan hidangan makan malam ala warung yang pastinya akan semakin membuat tamu nyaman berlama-lama menghabiskan waktu di Hyatt Regency Yogyakarta.

\section{Analisis dan Interpretasi Data}

Karakteristik Responden

Peneliti melibatkan seluruh karyawan di Food and Beverage Product Kitchen di Hyatt 
Regency Yogyakarta yang berjumlah 10 orang sebagai responden dalam penelitian mengenai keterampilan berbahasa Inggris yang dimiliki para staff. Adakah Kemampuan berbahasa Inggris dari para staff memberi pengaruh terhadap kelancaran operasional di departemen Food and
Beverage Product Kitchen di Hyatt Regency Yogyakarta.

Berdasar penyebaran angket berhasil dikumpulkan, data responden laki-laki sebanyak 8 orang atau $80 \%$, dan responden perempuan sebanyak 2 orang atau $20 \%$.

Tabel 1. Jenis Kelamin

\begin{tabular}{cccccc}
\hline & & Frequency & Percent & Valid Percent & Cumulative Percent \\
\cline { 3 - 6 } Laki-Laki & 8 & 80.0 & 80.0 & 80.0 \\
Valid & Perempuan & 2 & 20.0 & 20.0 & 100.0 \\
& Total & 10 & 100.0 & 100.0 & \\
\hline
\end{tabular}

Dilihat dari tingkat usia karyawan, diperoleh data usia karyawan dari tingkat umur 18-30 tahun sebanyak 6 orang (60\%) dan umur 31-45 sebanyak 4 orang (40\%). Data tersebut dapat dilihat pada tabel yang berada dibawah ini.

Tabel 2. Umur

\begin{tabular}{cccccc}
\hline & \multicolumn{4}{c}{ Umur } \\
& & Frequency & Percent & Valid Percent & Cumulative Percent \\
\hline \multirow{2}{*}{ Valid } & $18-30$ & 6 & 60.0 & 60.0 & 60.0 \\
& $31-45$ & 4 & 40.0 & 40.0 & 100.0 \\
& Total & 10 & 100.0 & 100.0 & \\
\hline
\end{tabular}

Terlihat di tabel 4.3 bahwa rata-rata pendidikan responden di jenjang SMA dan yang sederajat sebanyak 6 orang (60\%), dan di jenjang Perguruan Tinggi sebanyak 4 orang (40\%).

Tabel 3. Pendidikan

\begin{tabular}{cccccc}
\hline \multirow{2}{*}{ Valid } & Frequency & Percent & Valid Percent & Cumulative Percent \\
\cline { 2 - 6 } & SMA sederajat & 6 & 60.0 & 60.0 & 60.0 \\
& Perguruan Tinggi & 4 & 40.0 & 40.0 & 100.0 \\
Total & 10 & 100.0 & 100.0 & \\
\hline
\end{tabular}

\section{Hasil Uji Instrumen}

Uji Validitas

Kriteria penilaian uji validitas adalah apabila $r$ hitung $>\mathrm{r}$ tabel (pada $\alpha=5 \%$ ) maka dapat dikatakan item kuisioner tersebut valid dan sebaliknya, apabila $r$ hitung $<\mathrm{r}$ tabel (pada $\alpha=$ $5 \%$ ) maka dapat dikatakan item kuisioner tersebut tidak valid. 
Tabel 4. Hasil Uji Validitas

\begin{tabular}{lllll}
\hline Variabel & Item Pertanyaan & r hitung & r tabel & Keterangan \\
\hline \multirow{2}{*}{ Kemampuan } & P1 & 0,788 & 0,707 & Valid \\
Membaca (X1) & P2 & 0,933 & 0,707 & Valid \\
Kemampuan & P3 & 0,906 & 0,707 & Valid \\
Berbicara (X2) & P5 & 0,933 & 0,707 & Valid \\
Kemampuan & P6 & 0,933 & 0,707 & Valid \\
Mendengarkan (X3) & P8 & 0,729 & 0,707 & Valid \\
& P9 & 0,920 & 0,707 & Valid \\
Kemampuan Menulis & P10 & 0,933 & 0,707 & Valid \\
(X4) & P11 & 0,920 & 0,707 & Valid \\
Kelancaran & P13 & 0,838 & 0,707 & Valid \\
Operasional (Y) & P14 & 0,841 & 0,707 & Valid \\
& P15 & 0,729 & 0,707 & Valid \\
\hline
\end{tabular}

Dari tabel diatas dapat diketahui bahwa seluruh butir pernyataan dapat dikatakan valid karena memiliki nilai signifikan $>0,707$.

Uji Reliabilitas

Uji Reliabilitasdilakukan terhadap butir pernyataan yang valid saja. Variabel akan dinyatakan reliabel apabila memiliki cronbach alpha sama atau lebih besar dari $r$ tabel 0,707 , dengan hasil berikut:

Tabel 5. Hasil Uji Reliabilitas

\begin{tabular}{crr}
\hline \multicolumn{3}{c}{ Reliability Statistics } \\
Cronbach's Alpha & N of Items \\
\hline .968 & 15 \\
\hline
\end{tabular}

Dari tabel hasil uji reliabilitas dengan metode cronbach alpha, hasilnya yang didapat lebih besar dari 0,707. Artinya item-item pernyataan reliabel

\section{Uji Normalitas}

Tabel 6. Hasil Uji Normalitas

\begin{tabular}{|c|c|c|}
\hline \multicolumn{3}{|c|}{ One-Sample Kolmogorov-Smirnov Test } \\
\hline & & Unstandardized Residual \\
\hline $\mathrm{N}$ & & 10 \\
\hline \multirow[t]{2}{*}{ Normal Parameters $^{\mathrm{a}}$} & Mean & .0000000 \\
\hline & Std. Deviation & .24744769 \\
\hline \multirow[t]{3}{*}{ Most Extreme Differences } & Absolute & .218 \\
\hline & Positive & .218 \\
\hline & Negative & -.113 \\
\hline Kolmogorov-Smirnov Z & & .689 \\
\hline Asymp. Sig. (2-tailed) & & .729 \\
\hline a. Test distribution is Normal. & & \\
\hline
\end{tabular}


Berdasarkan tabel output di atas data berdistribusi normalkarena diketahui bahwa nilai signifikansi Asyimp.Sig (2-tailed) sebesar 0,729 lebih besar dari 0,05.

\section{Uji Hipotesis}

\section{Uji Regresi Linier Berganda}

Tabel 7. Hasil Analisa Regresi Linier Berganda

\begin{tabular}{|c|c|c|c|c|c|}
\hline \multicolumn{6}{|c|}{ Coefficients $^{a}$} \\
\hline \multirow[t]{2}{*}{ Model } & \multicolumn{2}{|c|}{$\begin{array}{l}\text { Unstandardized } \\
\text { Coefficients }\end{array}$} & \multirow{2}{*}{$\begin{array}{c}\text { Standardized } \\
\text { Coefficients } \\
\text { Beta } \\
\end{array}$} & \multirow[b]{2}{*}{$\mathbf{t}$} & \multirow[b]{2}{*}{ Sig. } \\
\hline & B & Std. Error & & & \\
\hline (Constant) & 1.829 & 1.026 & & 1.783 & .135 \\
\hline Kemampuan Membaca & .745 & .233 & .791 & 3.204 & .024 \\
\hline Kemampuan Berbicara & .013 & .123 & .019 & .107 & .919 \\
\hline $\begin{array}{l}\text { Kemampuan } \\
\text { Mendengarkan }\end{array}$ & -.147 & .176 & -.212 & -.838 & .440 \\
\hline Kemampuan Menulis & .262 & .082 & .429 & 3.196 & .024 \\
\hline \multicolumn{6}{|c|}{ a. Dependent Variable: Kelancaran Operasional } \\
\hline
\end{tabular}

Dari hasil tabel diatas, dapat diketahui persamaan regresi linierberganda yang diperoleh sebagaiberikut:

\section{$\mathrm{Y}=1,829+0,745 \mathrm{X} 1+0,13 \times 2-0,147 \mathrm{X3}+$ $0,262 \times 4$}

Nilai konstanta sebesar 1,829. Artinya, jika $\mathrm{X} 1, \mathrm{X} 2, \mathrm{X} 3$, dan X4 nilainya adalah 0, maka nilai dari vriabel Y adalah 1,829.

Nilai koefisien regresi dari variabel X1 (Kemampuan Membaca) bernilai sebesar 0,745 , artinya jika variabel X1 mengalami kenaikan $1 \%$ maka variabel Kelancaran Operasionl akan meningkat sebesar 0,745. Koefisien bernilai positif artinya ada pengaruh yang positif antara kemampuan membaca terhadap kelancaran operasional.

Nilai koefisien regresi dari variabel X2 (Kemampuan Berbicara) bernilai sebesar 0,013 , artinya jika variabel X2 mengalami kenaikan $1 \%$ maka variabel Kelancaran Operasional akan meningkat sebesar 0,013. Koefisien bernilai positif artinya ada pengaruh yang positif antara kemampuan membaca terhadap kelancaran operasional.

Nilai koefisien regresi dari variabel X3 (Kemampuan Mendengarkan) bernilai sebesar -0,147, artinya jika variabel X3 mengalami kenaikan $1 \%$ maka variabel
Kelancaran Operasional akan meningkat sebesar $-0,147$. Koefisien bernilai negatif artinya ada pengaruh yang negatif antara kemampuan mendengarkan terhadap kelancaran operasional.

Nilai koefisien regresi dari variabel X4 (Kemampuan Menulis) bernilai sebesar 0,262 , artinya jika variabel X4 mengalami kenaikan $1 \%$ maka variabel Kelancaran Operasional akan meningkat sebesar 0,262. Koefisien bernilai positif artinya ada pengaruh yang positif antara kemampuan mendengarkan terhadap kelancaran operasional.

\section{Uji t}

Kemampuan Membaca (X1)

Berdasarkan uji partial pada tabel Coefficients, maka diperoleh hasil berdasarkan data statistik di atas, besar

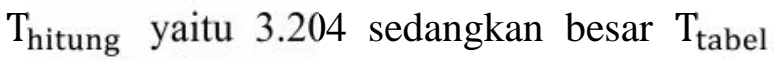
pada signifikan $5 \%$ dengan df $=n-k$, yaitu $\mathrm{df}=10-2=8$, besarnya adalah 2,306. Maka diperoleh $\mathrm{T}_{\text {hitung }}>\mathrm{T}_{\text {tabel }}$ maka dengan demikian hipotesis diterima artinya bahwa kemampuan membaca mempengaruhi kelancaran dalam operasional di food and beverage product.

Kemampuan Berbicara 
Berdasarkan uji partial pada tabel Coefficients, maka diperoleh hasilberdasarkan data statistik diatas, besar $\mathrm{T}_{\text {hitung }}$ yaitu 0,107 sedangkan besar statistik $\mathrm{T}_{\text {tabel }}$ pada signifikan $5 \%$ dengan $\mathrm{df}=\mathrm{n}-\mathrm{k}$, yaitu $\mathrm{df}=10-2:=8$, besarnya adalah 2,306 . Maka diperoleh $\mathrm{T}_{\text {hitung }}<\mathrm{T}_{\text {tabel }}$ maka dengan demikian hipotesis ditolak artinya bahwa kemampuan berbicara tidak mempengaruhi kelancaran operasional di food and beverage product.

\section{Kemampuan Mendengarkan}

Berdasarkan uji partial pada tabel Coefficients, maka diperoleh hasilberdasarkan data statistik diatas, besar

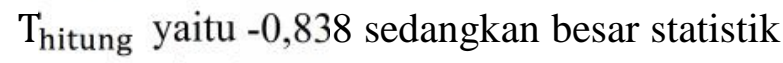
$\mathrm{T}_{\text {tabel }}$ pada signifikan $5 \%$ dengan $\mathrm{df}=\mathrm{n}-\mathrm{k}$, yaitu $\mathrm{df}=10-2:=8$, besarnya adalah 2,306 . Maka diperoleh $\mathrm{T}_{\text {hitung }}<\mathrm{T}_{\text {tabel }}$ maka dengan demikian hipotesis ditolak artinya variabel kemampuan mendengarkan tidak mempengaruhi kelancaran operasional di food and beverage product.

\section{Kemampuan Menulis}

Berdasarkan uji partial pada tabel Coefficients, maka diperoleh hasilberdasarkan data statistik diatas, besar $\mathrm{T}_{\text {hitung }}$ yaitu 1,196 sedangkan besar statistik $\mathrm{T}_{\text {tabel }}$ pada signifikan $5 \%$ dengan $\mathrm{df}=\mathrm{n}-\mathrm{k}$, yaitu $\mathrm{df}=10-2:=8$, besarnya adalah 2,306 . Maka diperoleh $\mathrm{T}_{\text {hitung }}>\mathrm{T}_{\text {tabel }}$ maka dengan demikian hipotesis diterima. Dapat diartikan bahwa kelancaran operasional di food and beverage dipengaruhi oleh kemampuan menulis.

\section{Uji R}

Tabel 8. Hasil Koefisien Determinasi (R)

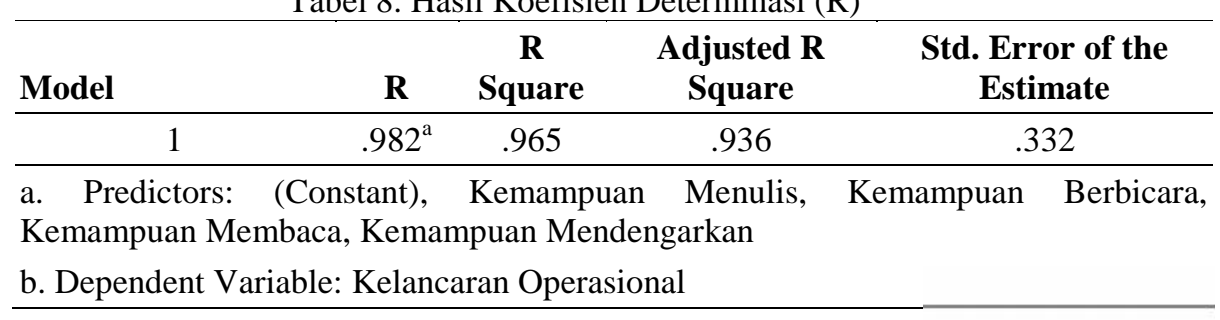

Dari hasil output SPSS diatas dapat dilihat bahwa nilai koefisiensi determinasi atau $\mathrm{R}$ Square sebesar 0,965 atau 96,5\%. Hal ini berarti variabel yang diteliti (kemampuan menulis, kemampuan berbicara, kemampuan membaca, kemampuan mendengarkan) secara simultan berpengaruh terhadap variabel Kelancaran Operasional sebesar 96,5\%. Sedangkan sisanya 3,5\% dipengaruhi oleh variabel lain di luar persamaan regresi ini atau variabel yang tidak diteliti.

\section{Uji F}

Uji $F$ adalah pengujian semua variabel independen yang dilakukan secara serentak terhadap variabel dependen yaitu dengan membandingkan $\mathrm{F}_{\text {hitung }}$ yang dihasilkan oleh regresi linier berganda dengan nilai $F_{\text {tabel }}$ pada taraf signifikan $(\alpha=0,05)$.

Pengambilan keputusan berdasarkan pada Nilai $F_{\text {hitung }}>F_{\text {tabel }}$ maka Ha diterima Ho ditolaksedangkan jika Nilai $F_{\text {hitung }}<F_{\text {tabel }}$ maka Ha ditolak Ho diterima

Analisa hasil uju F (simultan) dimaksudkan untuk membuktikan bahwa variabel kualitas pelayanan secara bersama-sama memiliki pengaruh yang signifikan terhadap kelancaran operasional. 
Tabel 9. Hasil Uji Serempak (F)

\begin{tabular}{ccccccr}
\hline \multicolumn{7}{c}{ ANOVA $^{\mathbf{b}}$} \\
Model & Sum of Squares & df & Mean Square & F & Sig. \\
\hline Regression & 15.049 & 4 & 3.762 & 34.135 & $.001^{\mathrm{a}}$ & \\
Residual & .551 & 5 & .110 & & \\
Total & 15.600 & 9 & & & \\
\hline
\end{tabular}

a. Predictors: (Constant), Kemampuan Menulis, Kemampuan Berbicara,

Kemampuan Membaca, Kemampuan Mendengarkan

b. Dependent Variable: Kelancaran Operasional

Berdasarkan tabel diatas diketahui bahwa

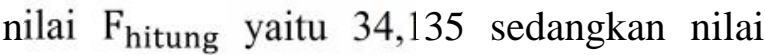
$\mathrm{F}_{\text {tabel }}$ dapat diperoleh dari $(\mathrm{k} ; \mathrm{n}-\mathrm{k})$ diatas menunjukan bahwa $\mathrm{k}=4$ dan $\mathrm{n}=10$, selanjutnya angka tersebut dimasukan kedalam rumus $(4 ; 10-4)=(4 ; 6)$, angka ini menjadi acuan untuk mengetahui nilai $F_{\text {tabel }}$ pada distribusi nilai $\mathrm{F}_{\text {tabel }}$. Besarnya $\mathrm{F}_{\text {tabel }}$ yaitu 4,53.

Diketahui nilai $\mathrm{F}_{\text {hitung }} 34,135>\mathrm{F}_{\text {tabel }} 4,53$, dengan nilai signifikan $0,001<0,05$, maka Ho ditolak artinya variabel X1, X2, X3, dan $\mathrm{X} 4$ secara simultan berpengaruh terhadap variabel $\mathrm{Y}$ (kelancaran operasional di food and beverage product).

\section{Pembahasan}

Hasil penelitian ini menunjukkan bahwa kelancaran operasional dipengaruhi oleh keterampilan berbahasa Inggris. Hal ini dikarenakan di hotel yang berstandar internasional bahasa Inggris digunakan dalam kegiatan operasional, sehingga keterampilan berbahasa Inggris sangat diperlukan dan berpengaruh terhadap operasional.

Hal tersebut dibuktikan dari hasil uji $\mathrm{F}$ dalam (tabel 4.9),diperoleh nilai $F_{\text {hitung }}$ sebesar 34,135 lebih besar dari nilai $F_{\text {tabel }} 4,53$, $F_{\text {hitung }}>F_{\text {tabel }}$ berarti Ho ditolak, artinya bahwa secara bersama sama (simultan/serempak) ada pengaruh yang signifikan antara kemampuan membaca, kemampuan berbicara, kemampuan mendengarkan, dan kemampuan menulis terhadap kelancaran operasional.

Nilai koefisiensi determinasi atau R Square sebesar 0,965 atau $96,5 \%$ berada diantara 0 dan 1, namun mendekati angka 1 (lihat tabel 4.8). Hal ini berarti variabel yang diteliti (kemampuan menulis, kemampuan berbicara, kemampuan membaca, kemampuan mendengarkan) berpengaruh terhadap variabel Kelancaran Operasional sebesar $96,5 \%$. Sedangkan sisanya 3,5\% dipengaruhi oleh variabel lain di luar persamaan regresi ini atau variabel yang tidak diteliti.

Terlihat di (tabel 4.7) bahwa nilai signifikansi dari variabel kemampuan membaca sebesar 0,024, dan $t_{\text {hitung }} 3,204>t_{\text {tabel }} 2,306$ berarti Ho ditolak yang bermakna bahwa kemampuan membaca mempengaruhi kelancaran operasional di food and beverage product. Nilaisignifikansi dari variabel kemampuan berbicara 0,919 dengan $t_{\text {hitung }}=0,107$, sehingga didapat nilai $t_{\text {hitung }} 0,107<t_{\text {tabel }} 2,306$ berarti Ho diterima maknanya kemampuan berbicara tidak berpengaruh dalam kelancaran operasional secara partial. Nilai signifikansi dari variabel kemampuan mendengarkan 0,440, dengan $\mathrm{t}_{\text {hitung }}-0,838<\mathrm{t}_{\text {tabel }} 2,306$ berarti Ho diterima maknanya kemampuan mendengarkan secara partial tidak berpengaruh terhadap kelancaran operasional di food and beverage product. Nilai signifikansi dari variabel kemampuan menulis sebesar 0,024, dengan $t_{\text {hitung }} 3,196>t_{\text {tabel }}$ 2,306berarti Ho ditolak yang bermakna bahwa ada pengaruh antara kemampuan menulis terhadap kelancaraan operasional, maka dapat dikatakan bahwa ada pengaruh yang positif antara variabel kemampuan membaca, kemampuan berbicara, kemampuan mendengarkan, kemampuan menulis terhadap variabel kelancaran operasional. Bila dibandingkan dengan variabel yang lain, kemampuan 
membaca memberikan pengaruh paling besar terhadap kelancaran operasional.

Hal ini terungkap pula dari hasil wawancaradengan karyawan yang memiliki jabatan Chef de Partie (Leman Sulaiman). Saat diwawancarai mengenai pengaruh keterampilan berbahasa Inggris terhadap kelancaran operasional, dinyatakan bahwa keterampilan berbahasa Inggris sangat penting dan dibutuhkan di hotel bintang 5 yang bertaraf Internasional-tidak saja dibagian office, di kitchen juga diperlukan, karena bahan baku masakan yang ada di setiap resep masakan menggunakan bahasa asing, peralatan, dan teknik memasak hampir semua menggunakan bahasa Inggris.

Peneliti juga melakukan observasi dengan hasil yaitu keterampilan berbahasa Inggris sangat berpengaruh terhadap kelancaran operasional terutama kemampuan membaca dan menulis. Ternyata kebanyakan bahan makanan, nama peralatan, bahan baku masakan, memo, dan nota pemesanan bahan menggunakan istilah bahasa Inggris. Jika karyawan tidak dapat memahami istilah bahasa Inggris tentu saja ini dapat berpengaruh terhadap kelancaran operasional seperti kesalahan dalam melakukan instruksi dalam mengolah makanan, salah dalam mengambil bahan makanan, hingga salah membuat pesanan tamu yang tentu saja hal tersebut dapat menghambat kelancaran operasional di Food and Beverage Product Kitchen.

Dari penjelasan diatas maka dapat disimpulkan bahwa kemampuan membaca dan menulis memiliki pengaruh yang besar terhadap kelancaran operasional. Hal ini karena kemampuan membaca dan menulis sangat diperlukan terutama untuk membaca dan menulis memo, bahan masakan, peralatan memasak, nota pemesanan makanan, dan metode masakan yang semuanya menggunakan bahasa Inggris.

Keterampilan berbahasa Inggris harus selalu ditingkatkan oleh para karyawan hotel ataupun perusahaan yang memiliki standar internasional, karena keterampilan berbahas Inggris yang baik tentu saja memperlancar operasional di hotel ataupun perusahaan internasional tersebut.

\section{SIMPULAN}

Berdasarkan penelitian yang telah dilakukan, maka dapat disimpulkan hasil penelitian bahwa pengaruh keterampilan berbahasa Inggris terhadap kelancaran operasional dapat dijelaskan dengan melihat $F_{\text {hitung }}$ sebesar 34,135> $F_{\text {tabel }}$ sebesar 4,53 dengan nilai signifikan $0,001<0,05$, maka Ho ditolak dan $\mathrm{Ha}$ diterima. Artinya bahwa variabel kemampuan menulis, kemampuan berbicara, kemampuan membaca, kemampuan mendengarkan secara simultan berpengaruh terhadap variabel kelancaran operasional.

Dilihat bahwa nilai koefisiensi determinasi atau R Square sebesar 0,965 atau 96,5\%. Hal ini berarti variabel yang diteliti (kemampuan menulis, kemampuan berbicara, kemampuan membaca, kemampuan mendengarkan) secara simultan berpengaruh terhadap variabel Kelancaran Operasional sebesar $96,5 \%$. Sedangkan sisanya 3,5\% dipengaruhi oleh variabel lain yang tidak diteliti.

Dilihat dari hasil koefisien regresi masingmasing variabel independen yaitu variabel kemampuan membaca bernilai sebesar 0,745, variabel kemampuan berbicara bernilai sebesar 0,013, kemampuan mendengarkan bernilai sebesar $-0,147$, kemampuan menulis bernilai sebesar 0,262. Berdasarkan hasil tersebut dapat disimpulkan bahwa variabel kemampuan membaca lebih dominan berpengaruh daripada variabel independen lainnya, artinya kemampuan membaca yang berpengaruh dominan terhadap kelancaran operasional di Food and Beverage Product Kitchendi Hyatt Regency Yogyakarta.

Dari penjelasan diatas maka dapat disimpulkan bawa kemampuan membaca dan menulis memilki pengaruh yang besar terhadap kelancaran operasional. Hal ini karena kemampuan membaca dan menulis sangat diperlukan terutama untuk membaca dan menulis memo, bahan masakan, peralatan memasak, nota pemesanan 
makanan, dan metode masakan yang semuanya menggunakan bahasa Inggris.

Berdasarkan hasil kesimpulan diatas, maka dapat diusulkan saran dari penulis yang dianggap perlu untuk perusahaan. Pihak hotel diharapkan dapat mengadakan pelatihan atau kursus untuk meningkatkan kemampuan berbahasa Inggris para karyawannya, sehingga dapat menambah kemampuan berbaha asing (Inggris) demi kelancaran operasional di Food and Beverage ProductKitchen. Pihak hotel diharapkan dapat memotivasi para karyawannya dengan cara membiasakan menggunakan bahasa Inggris dan tidak mentertawakan bila terjadi kesalahan, sehingga karyawan pun terbiasa dan tidak malu untuk menggunakan bahasa Inggris. Pihak hotel juga dapat meningkatkan standar persyaratan saat melakukan perekrutan karyawan baru, terutama dalam persyaratan kemampuan berbahasa Inggris.

\section{REFERENSI}

Bartono, P. H., \& Ruffino, E. M. (2006). Dasar-dasar Food Product Panduan untuk Uji Kompetensi. Yogyakarta: Anim Offset.

Bartono, P. H., \& Ruffino, E. M. (2010). Teknik Supervisi \& Uji Kompetensi untuk Pendidikan Pariwisata. Yogyakarta: CV Andi.

Keraf, G. (1997). Fungsi Bahasa sebagai Alat komunikasi Alat Komunikasi. Jurnal Studi Bahasa dan Komunikasi, 2(1).

Halliday, M. A. K., \& Hasan, R. (1989). Language, Context, and Text: Aspects of Language in a Social-Semiotic Perspective.

Ngalimun, S., \& Pd, M. (2014). Strategi dan Model Pembelajaran. Yogyakarta: Aswaja Pessindo

Ngalimun, F. (n.d.). M., \& Salabi, A. 2016. Strategi dan Model Pembelajaran.
Rachman, A. (2010). Pengaruh pelaksanaan servive quality terhadap tingkat kepuasan konsumen: studi kasus pada hotel mustika Tuban

Rahardi, R. K. (2001). Renik-renik Peradaban. Duta Wacana University Press.

Siahaan, S. (2008). Issues in Linguistics. Yogyakarta: Graha Ilmu.

Sugiyono, P. D. (2017). Metode Penelitian Pendidikan: Pendekatan Kuantitatif, Kualitatif, $R \& D$ (Cetakan Ke). Bandung: CV Alfabeta.

Sugiyono, P. (2011). Metodologi penelitian kuantitatif kualitatif dan $R \& D$. Alpabeta, Bandung.

Sulastiyono, A. (2011). Seri Manajemen Usaha Jasa Sarana Pariwisata dan Akomodasi Manajemen

Penyelenggaraan Hotel. Bandung: Alfabeta.

Wahyuni, S., \& Ibrahim, S. (2012). Asesmen Pembelajaran Bahasa. Bandung: Refika Aditama.

\section{PROFIL PENULIS}

\section{Nuharani Erningdyah Kurniyati,} merupakan dosen Sekolah Tinggi Pariwisata AMPTA Yogyakarta. Penulis memiliki kepakaran dalam bidang Bahasa Inggris pariwisata

\section{Id Scholar}

https://scholar.google.com/citations?hl=id\&a uthuser $=1$ \&user=4Zae6mUAAAAJ 